\title{
The Taxonomic Position of Obesumbacterium proteus, a Common Brewery Contaminant
}

\author{
By F. G. PRIEST, H. J. SOMERVILLE*, J. A. COLE AND \\ J. S. HOUGH \\ Department of Biochemistry, University of Birmingham, Birmingham, BI $52 T T$
}

(Received 26 October 1972)

\begin{abstract}
SUMMAR Y
The mole fraction of guanine plus cytosine in the DNA from Obesumbacterium proteus was $48 \%$, similar to that of Hafnia alvei, Salmonella gallinarum and the RM bacterium. DNA:DNA competition studies indicated that $O$. proteus strains fall into two groups, both of which could reasonably be included in the family Enterobacteriaceae. The same two groups were apparent from a numerical taxonomic investigation of 19 O. proteus strains which included 16 brewery isolates. The simple matching coefficients $(\% \mathrm{~S})$ were calculated from results of 50 biochemical and taxonomic tests, and a dendrogram was constructed. Every $O$. proteus isolate had the characteristics of the family Enterobacteriaceae. The two subgroups united at $86 \% \mathrm{~S}$, and formed a cluster with Hafnia and Salmonella strains at $72.5 \% \mathrm{~S}$. The difference between Hafnia alvei and $O$. proteus was almost entirely due to their different vigour rating. Furthermore, in a simulated brewery fermentation, two strains of $H$. alvei grew in a mixed culture with yeast. This was originally the defining characteristic of the genus Obesumbacterium.

We propose that reference to the genus Obesumbacterium should be discontinued, and that O. proteus should be placed in the genus Hafnia as Hafnia protea comb. nov.
\end{abstract}

\section{INTRODUCTION}

Obesumbacterium proteus has for many years been a taxonomic enigma (Shimwell, 1948; Shimwell, I964). When first isolated it was named Flavobacterium proteus (Shimwell, I936; Shimwell \& Grimes, 1936). Its dissimilarity with other members of this genus led to the proposal of a new genus Obesumbacterium with a single species whose distinctive feature was an ability to grow alongside yeast during a brewery fermentation (Shimwell, 1964).

However, cultures of yeast and bacteria are not uncommon. A bacterium CII 9 grows with the yeast Toropsula glabrata in the stomachs of new-born lambs (R. W. White, personal communication), and synergism occurs between Proteus mirabilis and Saccharomyces carlsbergensis in a steady state continuous culture (Chao \& Reilly, 1972). Thus the ability to grow alongside yeast in a brewery is a poor criterion for defining a genus and has the disadvantage of excluding closely related organisms because they have not been encountered in a brewery environment. A more rational classification of Obesumbacterium proteus has therefore been attempted.

* Present address: Borden Microbiological Laboratory, Shell Research Limited, Sittingbourne, Kent. 
Table I. Strains used and their source

\begin{tabular}{|c|}
\hline Drganism \\
\hline Obesumbacterium proteus 500 \\
\hline O. proteus $50 \mathrm{I}$ \\
\hline O. proteus 502 \\
\hline O. proteus ( 16 strainst) \\
\hline Hafnia alvei NCTC 8108 \\
\hline H. alvei NCTC 8112 \\
\hline H. alvei NCTC 9540 \\
\hline Escherichia coli WI 485 \\
\hline E. coli $\mathrm{B}$ \\
\hline Salmonella typhimurium LT2 \\
\hline S. gallinarum NCTC 5453 \\
\hline S. pullorum NCTC 5776 \\
\hline Klebsiella aerogenes $\mathrm{S} 2 \mathrm{O} 3$ \\
\hline K. aerogenes $\mathrm{NCTC} 8172$ \\
\hline K. edwardsii var. edwardsii NCTC 5054 \\
\hline K. edwardsii var. atlantae NCTC 9496 \\
\hline Proteus mirabilis $\mathrm{P9}$ \\
\hline P. vulgaris \\
\hline RM bacterium RM3 \\
\hline Enterobacter aerogenes NCTC 10006 \\
\hline E. aerogenes $\mathrm{HG} 4$ \\
\hline Chromobacterium typhiflavum NCTC \\
\hline $\begin{array}{l}\text { Citrobacter freundii NCTC } 79 \\
\text { Organism CI I9 }\end{array}$ \\
\hline
\end{tabular}

Source*
NCIB 8769
NCIB 8770
NCIB 877 I
Brewery isolates
NCTC
NCTC
NCTC
NCIB 948 I
M. Jones-Mortimer
M. Jones-Mortimer
NCTC
NCTC
J. A. Cole
NCTC
NCTC
NCTC
T. W. Young
Medical isolate
NCTC IO476
NCTC
Brewery isolate
NCTC
NCTC
R. W. White

* NCTC, National Collection of Type Cultures; NCIB, National Collection of Industrial Bacteria.

$\uparrow$ The individual $O$. proteus strain numbers are given in Fig. 4 and 5 .

Organisms and growth conditions

METHODS

Obesumbacterium proteus strains were isolated from brewery pitching yeasts. The yeast was diluted in physiological saline, plated on to MacConkey agar containing $200 \mu \mathrm{g} / \mathrm{ml}$ actidione (Upjohn Co., Kalamazoo, Michigan, U.S.A.) and incubated at $30^{\circ} \mathrm{C}$ for $48 \mathrm{~h}$. Gram-negative, lactose-negative colonies were purified by single colony isolation on the above media and retained as presumptive $O$. proteus strains. These bacteria and 18 strains representing eight genera of Enterobacteriaceae were maintained at $4{ }^{\circ} \mathrm{C}$ by monthly subculture on nutrient agar slopes. Their names and origins are shown in Table I.

Obesumbacterium proteus strains were grown in nutrient broth containing $0.5 \%(\mathrm{w} / \mathrm{v})$ glucose for $48 \mathrm{~h}$ at $30^{\circ} \mathrm{C}$ on a reciprocal shaker. Other organisms were grown in minimal media (Clowes \& Hayes, I968) at their optimum growth temperatures. To prepare ${ }^{14} \mathrm{C}$ labelled DNA, bacteria were grown in minimal medium containing $0.5 \%(\mathrm{w} / \mathrm{v})$ Casamino acids (Difco) until the extinction at $625 \mathrm{~nm}$ was 0.6 . Adenine $\left(8-{ }^{14} \mathrm{C} ; 50 \mu \mathrm{Ci} / 200 \mathrm{ml}\right.$ medium) was added and the cells grown until the extinction had doubled. The bacteria were harvested by centrifuging and washed twice with $0 \cdot 0$ I M-potassium phosphate buffer ( $\mathrm{pH} \mathrm{6.0)}$.

\section{Simulation of a brewery environment}

Hopped wort was prepared in the model brewery of the British School of Malting and Brewing and was collected aseptically in fermentation tubes ( $\mathrm{m} \times 5 \mathrm{~cm}$ diam.) in I 1 quantities. The specific gravity was I 045 . Saccharomyces cerevisiae NCYC 1062 was grown in media containing $(\mathrm{g} / \mathrm{l})$ : yeast extract, 3 ; malt extract, 3 ; peptone, 10 ; and glucose, 10. 
Sterile medium (i.e. in 21 conical flasks) was seeded with $10^{6}$ yeast $/ \mathrm{ml}$ and incubated for $72 \mathrm{~h}$ on a reciprocal shaker at $25^{\circ} \mathrm{C}$. The yeast was centrifuged, washed in sterile water, and resuspended in sterile water. Bacterial cultures were grown in the same medium for $48 \mathrm{~h}$ at $25{ }^{\circ} \mathrm{C}$, centrifuged, washed, and resuspended in sterile isotonic saline $(0.85 \%, \mathrm{w} / \mathrm{v})$.

Fermentation tubes were inoculated with $10^{5}$ bacteria $/ \mathrm{ml}$ and $10^{7}$ yeast $/ \mathrm{ml}$ and incubated at $\mathrm{I} 8{ }^{\circ} \mathrm{C}$. Samples taken through a suba seal stopper fitted halfway up the tubes were plated on to nutrient agar containing $100 \mu \mathrm{g}$ actidione $/ \mathrm{ml}$ after dilution in physiological saline. The plates were incubated at $30^{\circ} \mathrm{C}$ for $48 \mathrm{~h}$.

\section{Conventional taxonomy and data analysis}

All cultures were subjected to 50 physiological and biochemical tests as described by Bascomb, Lapage, Willcox \& Curtis (I97I) with two exceptions: motility was sought by phase contrast microscopy, and the carbohydrate concentration in fermentation tests was $0.5 \%(\mathrm{w} / \mathrm{v})$. All properties were recorded as positive or negative with weakly positive results scored positive. Tests that gave either all positive or all negative results for the 37 strains were not included in the calculation of the similarities.

Coded data were analysed on an Elliot 4I30 computer at the Microbial Systematics Unit, Leicester University, to obtain simple matching coefficients (Sokal \& Michener, 1958). A second programme used the average linkage cluster technique to sort the organisms into groups of high phenetic similarity (Sokal \& Sneath, 1963), and a dendrogram was constructed.

The proportion of positive results displayed by each organism was calculated as a measure of its 'vigour' (Sneath, 1968). A second similarity matrix was constructed eliminating the influence of vigour differences between the organisms and from this the average linkage cluster technique was used to develop a second dendrogram.

\section{DNA preparation, buoyant density and hybridization}

DNA was prepared as described by Somerville \& Jones (1972) and was stored at $4{ }^{\circ} \mathrm{C}$ over chloroform. Sheared DNA of molecular weight approximately $5 \times 15^{5}$ was prepared by passage through a French Press at 10000 to $15000 \mathrm{lb} / \mathrm{in}^{2}$ (McCarthy \& Bolton, 1963) and stored at $-16{ }^{\circ} \mathrm{C}$.

The buoyant density of DNA in caesium chloride was measured in a Spinco Model E analytical ultracentrifuge (Schildkraut, Marmur \& Doty, I962). Proteus mirabilis DNA was used as a reference either alone or with Klebsiella aerogenes S 203 DNA. The equation developed by De Ley (1970) was used to calculate the GC content from the buoyant density data.

DNA was immobilized on filters as described by Johnson \& Ordal (1968). DNA (50 $\mu \mathrm{g} / \mathrm{ml}$, $87 \mathrm{ml}$ ) was denatured by boiling for $10 \mathrm{~min}$ in $0 . \mathrm{I} \times \mathrm{SSC}$ (SSC is $0.0 \mathrm{I} 5 \mathrm{M}$-trisodium citrate and $0.15 \mathrm{M}-\mathrm{NaCl}$ ) and was quickly cooled by diluting to $5 \mu \mathrm{g} / \mathrm{ml}$ with cooled $6 \times \mathrm{SSC}$. The solution was passed $(60 \mathrm{ml} / \mathrm{min})$ through a $15 \mathrm{~cm}$ Millipore HAWP filter. When the filter was almost dry, $30 \mathrm{ml}$ of $0.02 \%(\mathrm{w} / \mathrm{v})$ bovine serum albumin (Armour Pharmaceutical Co., Eastbourne, Sussex), $0.01 \%(w / v)$ polyvinylpyrollidone (Calbiochem, La Jolla, California, U.S.A.), $0.02 \%(\mathrm{w} / \mathrm{v})$ Ficoll (Pharmacia, Uppsala, Sweden) in $2 \times \mathrm{SSC}$ was added, and after standing for $10 \mathrm{~min}$, the filter was sucked dry. After drying in air at $20{ }^{\circ} \mathrm{C}$ for $16 \mathrm{~h}$ small filters $(10.5 \mathrm{~mm}$ diam.) were punched from the large filter.

For hybridization experiments, I $\mu \mathrm{g}$ sheared, radioactive DNA in $0.05 \mathrm{ml} 0.1 \times \mathrm{SSC}$ and I $50 \mu \mathrm{g}$ sheared competitor DNA in $0.15 \mathrm{ml} 0 . \mathrm{I} \times \mathrm{SSC}$ were added to $12 \times 50 \mathrm{~mm}$ glass vials. Competitor DNA was omitted from some control tubes; others contained homologous 


\section{Table 2. The GC content of DNA from Obesumbacterium proteus and some enterobacteria}

$\begin{array}{lc}\text { Organism } & \text { Mol \% GC } \pm \mathbf{I} \% \\ \text { Obesumbacterium proteus } 50 \mathrm{I} & 48 \cdot 0 \\ \text { O.proteus } 502 & 48 \cdot 5 \\ \text { O.proteus } 5 \mathrm{IO} & 48 \cdot 0 \\ \text { O.proteus } 5 \mathrm{II} & 48 \cdot 0 \\ \text { Hafnia alvei } \mathrm{NCTC} 8 \mathrm{I} 05 & 48 \cdot 0 \\ \text { H. alvei } \mathrm{NCTC} 9540 & 48 \cdot 5 \\ \text { RM bacterium NCTC I0476 } & 47 \cdot 5 \\ \text { Organism CI I9 (three strains) } & 49 \text { to } 50 \\ \text { Salmonella gallinarum } & 50 \cdot 0 \\ \text { * The figure for } S . \text { gallinarum has been taken from Hill (1966). }\end{array}$

competitor DNA. The tubes were stoppered and heated in a boiling water bath for $10 \mathrm{~min}$ and then cooled quickly on ice. To each tube $0.05 \mathrm{ml} \mathrm{9.6} \times \mathrm{SSC}$ was added followed by a $10.5 \mathrm{~mm}$ filter carrying unsheared DNA from the same organism as the radioactive DNA. Incubations were for $\mathrm{I} 6 \mathrm{~h}$ at 63 to $67^{\circ} \mathrm{C}$. Filters were washed three times with $2 \times \mathrm{SSC}$ at the temperature of incubation, blotted and dried at $60{ }^{\circ} \mathrm{C}$ for $\mathrm{I} h$. The radioactivity was measured using $0.7 \%$ (w/v) butyl PBD [2-(4'-t-butylphenyl)-5-(4 ${ }^{11}$-biphenylyl)-I,3,4oxadiazole] (Intertechnique Ltd, Portslade, Sussex) in toluene as scintillation fluid.

Results are expressed as $\%$ competition defined as:

$$
\% \text { competition }=\frac{x-y}{x-z} \times \mathrm{I} 00,
$$

where $x$ = radioactivity bound to filter in absence of competitor, $y=$ radioactivity bound in presence of heterologous competitor, $z=$ radioactivity bound with homologous competitor (Ballard et al. 1970). Each determination was the average of two duplicates.

Following a suggestion by Professor N. J. Palleroni, the following procedure was developed to determine the thermal dissociation profile. After counting, the filters were washed five times in toluene, blotted dry, washed three times in $2 \times \mathrm{SSC}$ at room temperature and once in $2 \times \mathrm{SSC}$ at the temperature of hybridization. Each filter was added to $0.5 \mathrm{ml} 2 \times \mathrm{SSC}$ at a temperature approximately $5{ }^{\circ} \mathrm{C}$ higher than that of the last wash. After Io min the filter was removed, blotted and added to fresh $2 \times \mathrm{SSC}$ at the same temperature. The temperature was raised by steps of about $5{ }^{\circ} \mathrm{C}$ and the process repeated to a maximum of $100{ }^{\circ} \mathrm{C}$. Samples from the tubes containing dissociated DNA were then counted in $0.8 \%(\mathrm{w} / \mathrm{v})$ butyl PBD, $8.5 \%(\mathrm{w} / \mathrm{v})$ naphthalene (scintillation grade, Koch-Light Laboratories, Colnbrook, Buckinghamshire) in dioxane. The radioactivity is expressed as $\%$ of total disintegrations/min dissociating up to, and including, $100{ }^{\circ} \mathrm{C}$. Less than $25 \%$ of the radioactivity from homologous hybridizations remained bound at $100{ }^{\circ} \mathrm{C}$ and less than $5 \%$ from heterologous hybridizations.

\section{RESULTS}

The results of 50 biochemical and physiological tests for Obesumbacterium proteus strains 502 and 510 were compared with those of all organisms recorded at the Computer Identification Centre. Three members of the family Enterobacteriaceae were named as nearest relatives, Hafnia alvei, the RM bacterium and Salmonella gallinarum.

Closely related organisms should contain essentially the same DNA GC content. DNA 
Table 3. \% Competition of DNA from various organisms with Obesumbacterium proteus DNA

\begin{tabular}{|c|c|c|}
\hline \multirow[b]{2}{*}{ Competitor DNA } & \multicolumn{2}{|c|}{$\begin{array}{l}\text { Radioactive DNA and DNA on filter } \\
\text { isolated from }\end{array}$} \\
\hline & $\begin{array}{l}\text { Obesumbacterium } \\
\text { proteus } 502 *\end{array}$ & $\begin{array}{l}\text { Obesumbacterium } \\
\text { proteus } 5 \mathrm{I} \dagger\end{array}$ \\
\hline Obesumbacterium proteus $5 \mathrm{II}$ & 100 & $100 \div$ \\
\hline O. proteus 502 & 100 & $100 \div$ \\
\hline O.proteus $50 \mathrm{I}$ & 77 & $85+$ \\
\hline O. proteus $5 \mathrm{IO}$ & 100 & $95 \div$ \\
\hline O. proteus 530 & 65 & $20 \div$ \\
\hline RM bacterium & 80 & $29+$ \\
\hline Hafnia alvei NCrC 8II2 & 70 & $82+$ \\
\hline Salmonella gallinarum & $17 \div$ & 0 \\
\hline S. typhimurium $\mathrm{LT2}$ & $7+$ & - \\
\hline Escherichia coli W 485 & 53 & $21 \div$ \\
\hline E. coli $\mathrm{B}$ & $81+$ & $59 \%$ \\
\hline Klebsiella aerogenes $\mathrm{S} 203$ & $17 t$ & $\underline{-1}$ \\
\hline Proteus mirabilis & of & of \\
\hline P. vulgaris & $2 \mathrm{I}$ & $5 \div$ \\
\hline
\end{tabular}

from Obesumbacterium proteus, Hafnia alvei and the RM bacterium contained $48 \%$ GC whereas that from Salmonella gallinarum and three strains of organism CI 19 contained slightly more GC (Table 2). These organisms were therefore included as reference strains for further studies

\section{DNA hybridization}

Table 3 shows the effect of excess DNA from various organisms on the binding of radioactive Obesumbacterium proteus DNA to filters containing homologous, unlabelled DNA. Obesumbacterium proteus 502, $5 \mathrm{I} 0$ and $5 \mathrm{II}$ gave $100 \%$ competition with $O$. proteus 502 and 95 to $100 \%$ competition with $O$. proteus $5 \mathrm{II}$. Strains $50 \mathrm{I}$ and 530 competed less effectively, but strain 50 I showed greater competition than 530 with 5I I DNA. Hafnia alvei, the RM bacterium and two strains of Escherichia coli gave 53 to $81 \%$ competition with O. proteus 502, and $2 \mathrm{I}$ to $82 \%$ competition with O. proteus 5 I I (Table 3 ).

When the radioactive DNA and the DNA bound to the filter were isolated from Escherichia coli WI 485 , Obesumbacterium proteus 502, 5 IO and 5I I DNA gave 27 to $43 \%$ competition, but DNA from strains $50 \mathrm{I}$ and 530 gave only $8 \%$ and I $\%$ competition respectively (Table 4). The competition shown by strains 502, 5IO and 5I I was within the range found with the enterobacteria listed in Table 4.

An alternative approach to competition is provided by comparing the direct binding of heterologous and homologous DNA (Brenner et al. 1969). Preparations of DNA from Escherichia coli WI 485 and Obesumbacterium proteus 502 were compared by this method under the same conditions used for competition, but in the absence of competitor DNA (Table 5). Obesumbacterium proteus DNA showed greater ability to associated with E. coli DNA, relative to homologous reassociation, than did $E$. coli DNA in the reciprocal experiment. A possible interpretation of these results is that $O$. proteus may have a smaller complement of DNA than E. coli. 
Table 4. \% Competition of DNA from various organisms with DNA from Escherichia coli $\mathrm{W} \mathrm{I} 485$

Competitor DNA

Obesumbacterium proteus $5 \mathbf{I} \mathbf{I}$

O. proteus 502

$O$. proteus $50 \mathrm{I}$

$O$. proteus 510

O. proteus 530

RM bacterium

Hafnia alvei NCTC 8I 12

Salmonella typhimurium LT2

Escherichia coli wI 485

E. coli $\mathbf{B}$

Klebsiella aerogenes $\mathrm{S} 203$

Proteus mirabilis

P. vulgaris
Experiment I*

\begin{tabular}{r}
30 \\
43 \\
11 \\
27 \\
8 \\
28 \\
22 \\
63 \\
100 \\
93 \\
\hline 50 \\
0
\end{tabular}

Experiment 2*

22

$-$

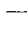

$-$

-

35

100

79

27

$=$

* Tubes were incubated for $16 \mathrm{~h}$ at $63^{\circ} \mathrm{C}$ in experiment $\mathrm{I}$ and for $16 \mathrm{~h}$ at $67^{\circ} \mathrm{C}$ in experiment 2 .

Table 5. Direct binding of radioactive DNA to homologous and heterologous $D N A$ on a filter

Hybridization was carried out at $67^{\circ} \mathrm{C}$ under the conditions used in Tables 3 and 4 but without competitor DNA.

DNA on filter

Escherichia coli w1 485

Obesumbacterium proteus 502

O. proteus 502

O. proteus 502
Radioactive DNA
in solution

E. coli $\mathrm{WI} 485$

E. coli $\mathrm{w}$ I 485

O. proteus 502

E. coli $\mathrm{WI} 485$
Radioactivity bound to filter (c.p.m.)

405

74
519

265
Relative reassociation $(\%)$

100

I 8

100

5 I

The thermal dissociation profiles were determined for DNA duplexes formed under conditions similar to those used in the preceding experiments (Fig. I $a, b, 2$ ). The temperature for $50 \%$ dissociation (apparent $T_{m}$ ) was 90 to $92{ }^{\circ} \mathrm{C}$ for homologous duplexes, 78 to $85{ }^{\circ} \mathrm{C}$ for heterologous duplexes between radioactive DNA from Escherichia coli wi 485 and Obesumbacterium proteus 502 DNA on the filter, and $85^{\circ} \mathrm{C}$ for duplexes between radioactive $O$. proteus 502 DNA and $E$. coli wI 485 DNA. The dissociation profiles may be slightly displaced, particularly for the heterologous duplexes, as some radioactivity $(<20 \%)$ was found in the buffer after the first incubation at $68^{\circ} \mathrm{C}$ : this has not been represented in the diagrams. The apparent $T_{m}$ may therefore be 2 to $3{ }^{\circ} \mathrm{C}$ too high for the heterologous duplexes.

\section{Numerical taxonomy}

A dendrogram was constructed from the simple matching coefficients ( $\% \mathrm{~S})$ (Fig. 3). It is evident that all the Obesumbacterium proteus strains form a cluster at the $73 \% \mathrm{~S}$ level which includes Salmonella gallinarum and $S$. pullorum. The three Hafnia alvei strains unite at the $82 \% \mathrm{~S}$ level and join the $O$. proteus strains at $72.5 \% \mathrm{~S}$. The RM bacterium shows greatest affinity to Escherichia coli; and Chromobacterium typhiflavum, S. typhimurium and Citrobacter freundii form solitary phenons at $75 \%$ S. Similarly the two Proteus species form a single group whilst organism CII9 joins the Klebsiella phenon at $80 \% \mathrm{~S}$. Finally the two Enterobacter species, comprising a typical strain and a brewery isolate, form their own cluster. Above the $86 \% \mathrm{~S}$ level the $O$. proteus strains fall into two major groups from which the avian salmonellae are excluded. Although they were isolated from widely different 

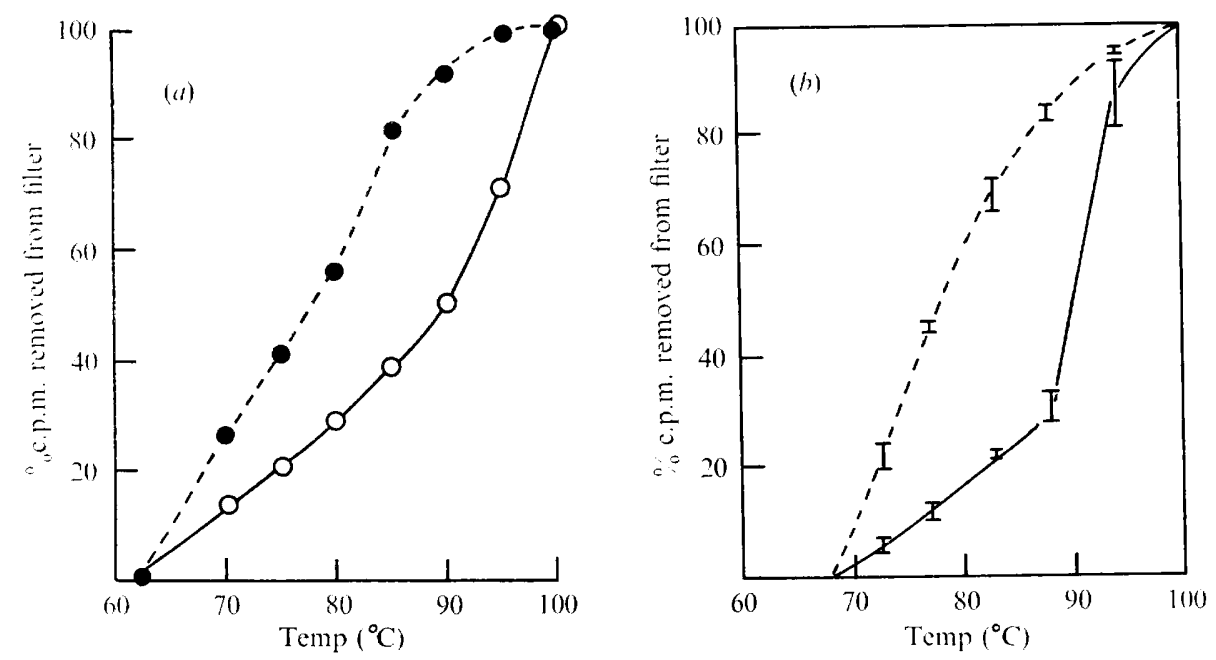

Fig. 1. Thermal dissociation of DNA duplexes formed with radioactive DNA from Escherichia coli WI 485 , and unlabelled DNA from Obesumbacterium proteus 502 or E. coli WI 485 on the filter. (a) Hybridization carried out at $63{ }^{\circ} \mathrm{C}$; (b) hybridization carried out at $67{ }^{\circ} \mathrm{C}$. The bars indicate results from duplicate experiments. Experimental details are given in the Methods.

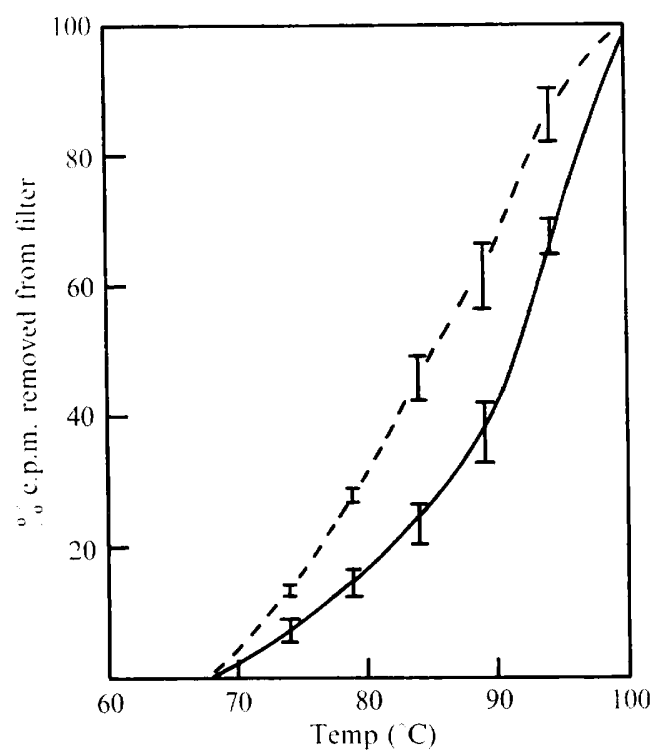

Fig. 2. Therma dissociation of DNA duplexes formed with radioactive DNA from Obesumbacterium proteus 502, and unlabelled DNA from Escherichia coli wI485 or O. proteus 502 on the filter. Hybridization was carried out at $67^{\circ} \mathrm{C}$. The bars indicate results from duplicate experiments.

geographical locations, O. proteus strain $50 \mathrm{I}$ was identical to strain 5 IO and 520 identical to strain 53 I over the range of tests chosen.

Vigour estimates of all the strains examined were expressed as the proportions of positive results (Table 6). Obesumbacterium proteus strains grew slowly, even in rich media, and this is reflected in their low vigour ratings. Only Salmonella gallinarum, S. pullorum and the RM 


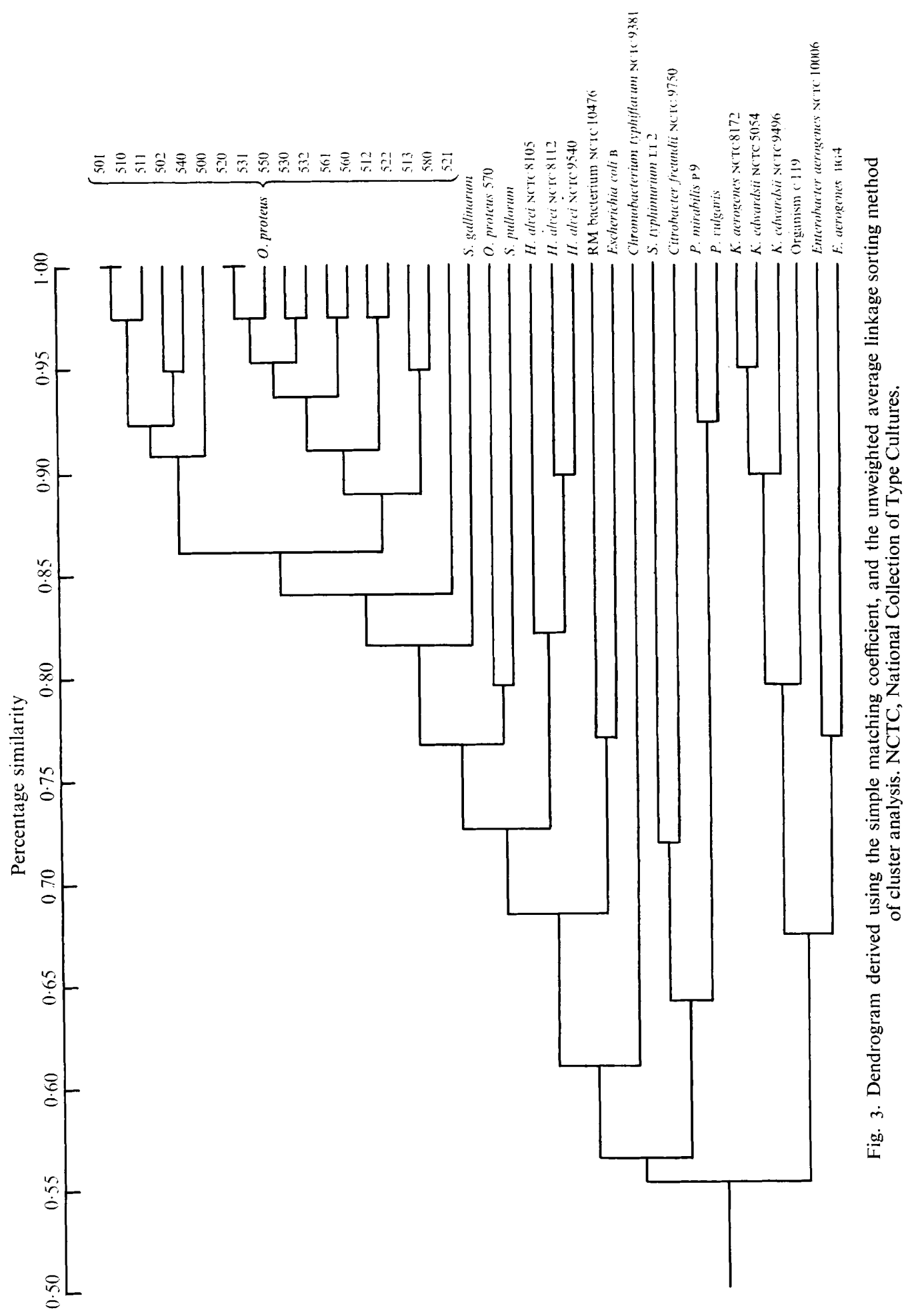




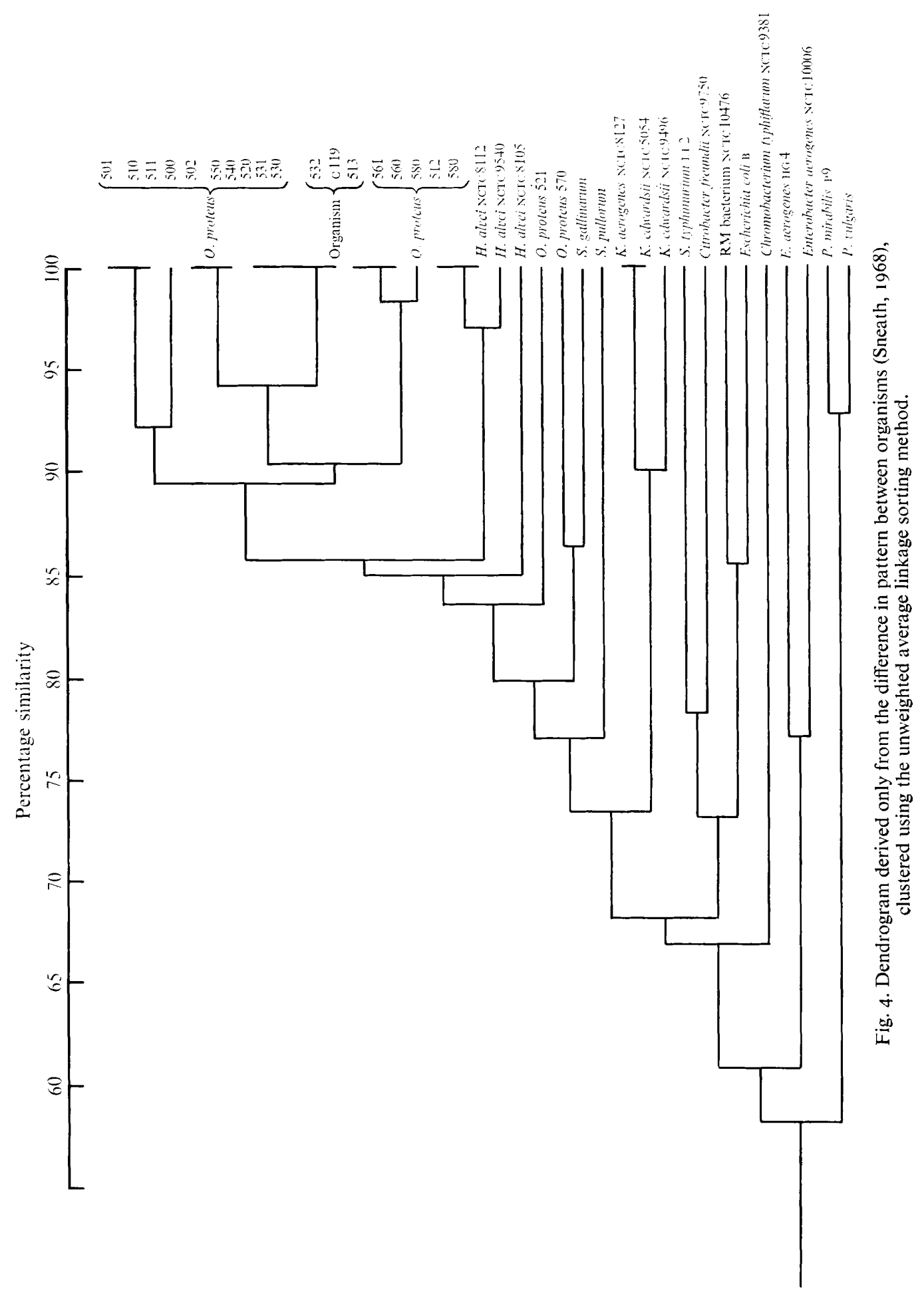


Table 6. Vigour estimates of Obesumbacterium proteus and reference organisms

\begin{tabular}{|c|c|c|c|}
\hline Organism & Vigour* & Organism & Vigour \\
\hline O. proteus 570 & 0.385 & Enterobacter aerogenes $\mathrm{HG} 4$ & $0.64 I$ \\
\hline 502 & 0.308 & E. aerogenes NCTC 10006 & 0.6 I 5 \\
\hline $5 \mathrm{II}$ & 0.282 & Citrobacter freundii NCTC 9750 & 0.615 \\
\hline 513 & 0.282 & Klebsiella edwardsii NCTC 5054 & 0.615 \\
\hline 580 & 0.282 & K. edwardsii NCTC 9496 & 0.590 \\
\hline $50 \mathrm{I}$ & 0.256 & $K$. aerogenes NCTC 8172 & 0.564 \\
\hline 510 & 0.256 & Proteus mirabilis $\mathrm{P9}$ & 0.573 \\
\hline 540 & 0.256 & P. vulgaris & 0.487 \\
\hline 532 & 0.256 & C. typhiflavum NCTC 938I & 0.487 \\
\hline 521 & 0.256 & Organism CII9 & 0.487 \\
\hline 522 & 0.256 & Hafnia alvei NCTC 9540 & 0.487 \\
\hline 530 & 0.231 & Escherichia coli $\mathbf{B}$ & 0.462 \\
\hline 512 & $0.23 I$ & H. alvei NCTC $8 \mathrm{I}$ I 2 & 0.436 \\
\hline 500 & 0.231 & Salmonella typhimurium $\mathbf{L T} 2$ & 0.436 \\
\hline 520 & 0.205 & H. alvei NCTC 8I05 & 0.410 \\
\hline 560 & 0.205 & RM bacterium NCTC 10476 & $0 \cdot 282$ \\
\hline 531 & 0.205 & S. pullorum NCTC 5776 & 0.282 \\
\hline 550 & 0.179 & S. gallinarum NCTC 5453 & $0.23 \mathrm{I}$ \\
\hline 561 & 0.179 & & \\
\hline
\end{tabular}

bacterium showed approximately equivalent levels of metabolic activity. The Enterobacter and Klebsiella species had the highest vigour ratings and fastest growth rates. The dendrogram derived from differences in metabolic pattern only is similar to that based on the total differences between the strains but the $\% \mathrm{~S}$ levels at which clusters are formed is higher (Fig. 4). Many of the $O$. proteus strains have identical patterns of metabolic activity. The two major groups are again evident and coalesce at $90 \% \mathrm{~S}$. The characteristics of the two $O$. proteus subgroups differ principally in the fermentation of mannitol, salicin and xylose (Table 7). The reactions for Hafnia alvei (Bascomb et al. 1971) are included for comparison.

With the exception that the characteristics of the edwardsii and atlantae varieties of Klebsiella edwardsii were identical in Fig. 4 but not in Fig. 3, the relationships between the marker strains were similar in both dendrograms. Organism CII 9 appeared to be identical to four Obesumbacterium proteus strains when the vigour component of the similarity was excluded, but Salmonella gallinarum and S. pullorum showed only $78 \% \mathrm{~S}$ and $75 \% \mathrm{~S}$ respectively.

\section{Growth of bacteria in simulated brewery fermentations}

Sterilized wort was inoculated with yeast and one of several species of enterobacteria. Numbers of surviving bacteria were determined after incubation at $30{ }^{\circ} \mathrm{C}$ for various times (Fig. 5). The population of Obesumbacterium proteus rose during the first $40 \mathrm{~h}$ of the fermentation, but subsequently fell. This decline in viable count was probably caused by the low $\mathrm{pH}$ and high alcohol concentration of the wort (see also Strandskov, Baker \& Bocklemann, I953; Case, 1965). Hafnia alvei grew during the first $30 \mathrm{~h}$ of the fermentation, and therefore appeared to be tolerant to the presence of the yeast. Enterobacter aerogenes failed to grow to any significant extent, and the viable count of the RM bacterium and of Citrobacter freundii declined throughout the incubation period. 
Table 7. The defining characteristics of the Obesumbacterium proteus groups and Hafnia alvei

\begin{tabular}{|c|c|c|c|}
\hline & Group I & Group 2 & Hafnia alvei \\
\hline Acid from PWS adenitol & - & - & - \\
\hline arabinose & - & d & + \\
\hline $\begin{array}{l}\text { cellobiose } \\
\text { dulcitol }\end{array}$ & - & - & d \\
\hline dulcitol & - & - & + \\
\hline glycerol & + & + & d \\
\hline inositol & - & - & - \\
\hline lactose & $\rightarrow$ & - & - \\
\hline (ONPG) & - & - & + \\
\hline maltose & + & + & + \\
\hline mannitol & + & - & + \\
\hline raffinose & - & - & - \\
\hline rhamnose & + & + & + \\
\hline salicin & + & - & - \\
\hline sorbitol & - & - & d \\
\hline starch & - & - & - \\
\hline sucrose & - & - & - \\
\hline trehalose & + & + & + \\
\hline xylose & - & + & $\mathrm{d}$ \\
\hline Gas from glucose PW & - & - & + \\
\hline Motility $37^{\circ} \mathrm{C}$ & - & - & d \\
\hline Motility $30^{\circ} \mathrm{C}$ & - & - & d \\
\hline Growth on MacConkey agar & + & + & + \\
\hline Liquefaction in gelatin I to 5 days & - & - & - \\
\hline Liquefaction in gelatin 5 to 30 days & - & - & - \\
\hline Citrate utilization & - & - & + \\
\hline KCN tolerance & d & d & + \\
\hline Gluconate & - & d & + \\
\hline Malonate & - & - & $\mathrm{d}$ \\
\hline Urease & - & - & - \\
\hline Indole & - & - & - \\
\hline $\mathrm{H}_{2} \mathrm{~S}$ (TSI Agar) & - & - & - \\
\hline $\mathrm{H}_{2} \mathrm{~S}$ paper (nutrient broth) & d & d & d \\
\hline Arginine decarboxylase & - & - & d \\
\hline Lysine decarboxylase & + & + & + \\
\hline Ornithione decarboxylase & + & + & + \\
\hline MR $37^{\circ} \mathrm{C}$ & d & - & d \\
\hline $\operatorname{MR} 30^{\circ} \mathrm{C}$ & d & - & d \\
\hline VP 37 & - & - & d \\
\hline VP 30 & - & - & + \\
\hline
\end{tabular}

,+ 90 to $100 \%$ of strains yield positive result; $\mathrm{d}$, I I to $89 \%$ of strains yield positive result; - , o to $10 \%$ of strains yield positive result. PW, peptone water; PWS, peptone water and appropriate sugar; MR, methyl red test; VP, Voges-Proskauer test; TSI, triple sugar iron medium; ONPG, $\sigma$-nitrophenyl- $\beta$-D-galactoside.

\section{DISCUSSION}

The taxonomic position of Obesumbacterium proteus has been problematic since it was first isolated: Shimwell (1948) even suggested its exclusion from the Eubacteriales. A reassessment is now possible on the basis of its DNA GC content, DNA/DNA competition experiments and Adansonian analysis of results of 50 tests with 19 O. proteus isolates and 18 reference strains.

Conventional biochemical and physiological tests established that Obesumbacterium proteus fulfills the criteria defining the family Enterobacteriaceae and shows a high overall level of similarity with other members. The I9 strains formed two clusters which coalesce 


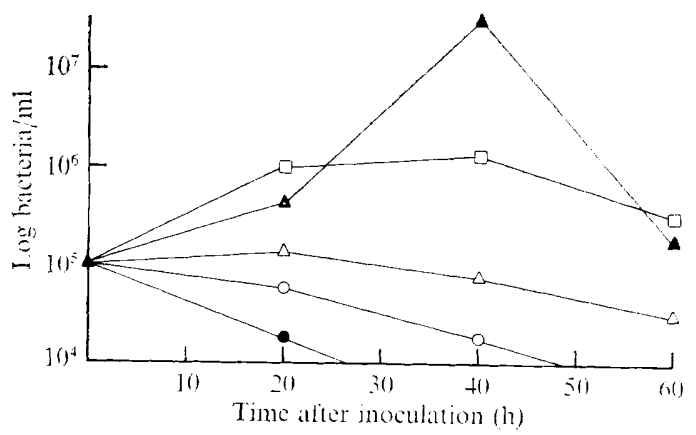

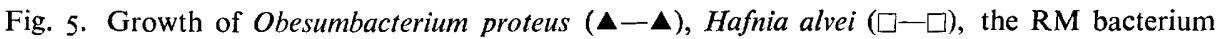
(-), Enterobacter aerogenes $(\triangle-\triangle)$, and Citrobacter freundii $(\mathrm{O}-\mathrm{O})$ with yeast in a simulated brewery environment.

at $86 \% \mathrm{~S}$. Their DNA GC content was not inconsistent with their assignment to the Enterobacteriaceae. DNA/DNA competition studies again indicated a possible subdivision of $O$. proteus into two groups, one consisting of strains 502, 5IO and 5I (Group I) and the other of strains $50 \mathrm{I}$ and 530 (Group 2) (Tables 3 and 4). Comparison with other members of Enterobacteriaceae indicate that the $O$. proteus strains can rightly be included in this family. Group I of $O$. proteus would appear to be more closely related to Escherichia coli than Group 2. The studies are not extensive enough to indicate the exact position of $O$. proteus relative to members of the Enterobacteriaceae.

The relationships between polynucleotides from members of Enterobacteriaceae have been studied in detail by Brenner and co-workers (Brenner, Martin \& Hoyer, 1967; Brenner \& Cowie, I968; Brenner et al. I969). In the present work, heterologous duplexes formed at $63{ }^{\circ} \mathrm{C}$ and $67.5{ }^{\circ} \mathrm{C}$ between DNA from Obesumbacterium proteus and Escherichia coli showed $T_{m}$ values 8 to I $3{ }^{\circ} \mathrm{C}$ below that of homologous duplexes (Fig. I $a, b, 2$ ). Homologous duplexes had $T_{m}$ values of 90 to $92{ }^{\circ} \mathrm{C}$, close to that expected for DNA with the base composition of $48 \%$ GC (Marmur \& Doty, I96I). The thermal stability of duplexes between $E$. coli DNA and $O$. proteus DNA was similar whichever DNA preparation was radioactive.

The value of vigour and pattern analysis has again been substantiated. When the high vigour displayed by Hafnia alvei is excluded from the calculation of the similarities, the pattern difference with Obesumbacterium proteus almost disappears. Thus $H$. alvei NCTC 8I I 2 is identical to $O$. proteus strains $5 \mathrm{I} 2$ and 580 and $H$. alvei NCTC 9540 joins at the $97 \% \mathrm{~S}$ level. Conversely Salmonella gallinarum and $S$. pullorum, organisms of low vigour, showed a high overall similarity with $O$. proteus, but on pattern difference alone were more distantly related. Organism $\mathrm{CI} I 9$ has a high vigour rating and, using the simple matching coefficient, it shows high affinity with the Klebsielleae. When the vigour component is excluded from the calculation of the similarity, it identifies with four $O$. proteus strains. Organism CII 9 has a GC content of $49 \%$, very similar to the $O$. proteus value of $48 \%$ and markedly different from the value of $55 \%$ for the Klebsielleae (Hill, I966).

Hafnia alvei strains NCTC $8 \mathrm{IO} 5$ and 8II 2 both grew with yeast in a simulated brewery fermentation, and therefore fulfilled the original criterion for the genus Obesumbacterium (Shimwell, I964). We suggest that reference to the genus Obesumbacterium be discontinued and that $O$. proteus be included in the genus Hafnia and renamed Hafnia protea comb. nov. Although both dendrograms (Fig. 3, 4) and results of DNA/DNA competition experiments suggest that the $O$. proteus strains fall into two groups, no differences in their activity in the brewery can be discerned. They should therefore be regarded as belonging to a single species. 
The authors thank Dr S. P. Lapage for advice and facilities and Mr M. Sackin for the computer analysis. F. G.P. thanks The Brewers' Society for a Research Studentship.

\section{REFERENCES}

Ballard, R. W., Palleroni, N. J., Doudoroff, M., Stanier, R. Y. \& Mandel, M. (I970). Taxonomy of the aerobic pseudomonads: Pseudomonas cepacia, $P$. marginata, $P$. alliicola and $P$. caryophylli. Journal of General Microbiology 6o, 199-2 I4.

Bascomb, S., Lapage, S. P., Willcox, W. R. \& Curtis, M. A. (I97I). Numerical taxonomy of the tribe Klebsiellae. Journal of General Microbiology 66, 279-295.

BrenNER, D. J. \& CowIE, D. B. (I968). Thermal stability of Escherichia coli-Salmonella typhimurium deoxyribonucleic acid duplexes. Journal of Bacteriology 95, 2258-2262.

Brenner, D. J., Fanning, G. R., Johnson, K. E., Citarella, R. V. \& Falkow, S. (1969). Polynucleotide sequence relationships among members of the Enterobacteriaceae. Journal of Bacteriology 95, 893-900.

Brenner, D. J., Martin, M. A \& Hoyer, B. H. (1967). Deoxyribonucleic acid homologies among some bacteria. Journal of Bacteriology 94, 486-487.

CASE, A. C. (1965). Conditions controlling Flavobacterium proteus in brewery fermentations. Journal of the Institute of Brewing 7r, 250-256.

CHAO, C. \& ReIlly, P. J. (1972). Symbiotic growth of Acetobacter suboxydans and Saccharomyces carlsbergensis in a chemostat. Biotechnology and Bioengineering 14, 75-92.

Clowes, R. C. \& Hayes, W. (1968). Experiments in Microbial Genetics. Oxford and Edinburgh: Blackwell Scientific Publications.

DE LEY, J. (I970). Re-examination of the association between melting point, buoyant density, and chemical base composition of deoxyribonucleic acid. Journal of Bacteriology 10r, 738-754.

HiLl, L. R. (I966). An index to deoxyribonucleic acid base compositions of bacterial species. Journal of General Microbiology 44, 419-437.

Johnson, J. L. \& Ordal, E. J. (I968). Deoxyribonucleic acid homology in bacterial taxonomy: effect of incubation temperature on reaction specificity. Journal of Bacteriology 95, 893-900.

MCCARThy, B. J. \& Bolton, E. T. (1963). An approach to the measurement of genetic relatedness among organisms. Proceedings of the National Academy of Sciences of the United States of America 50, $156-164$.

MARmur, J. \& Doty, P. (196r). Thermal denaturation of deoxyribonucleic acid. Journal of Molecular Biology 3, 585-594.

Schildkraut, C. L., Marmur, J. \& Doty, P. (1962). Determination of the base composition of deoxyribonucleic acid from its buoyant density in CsCl. Journal of Molecular Biology 4, 430-443.

SHImwell, J. L. (1936). A study of the common rod bacteria of brewer's yeast. Journal of the Institute of Brewing 42, 1 19-127.

Shimwell, J. L. (1948). Brewing bacteriology. V. Gram-negative wort, yeast and beer bacteria. Wallerstein Laboratories Communications $\mathbf{x}, 135-145$.

SHIMwell, J. L. (1964). Obesumbacterium, a new genus for the inclusion of ' Flavobacterium proteus'. Journal of the Institute of Brewing 70, 247-248.

Shimwell, J. L. \& Grimes, M. (1936). The distinguishing characters of Flavobacterium proteus (sp.nov.), the common rod bacterium of brewer's yeast. Journal of the Institute of Brewing 42, 348-350.

SNEATH, P. H. A. (1968). Vigour and pattern in taxonomy. Journal of General Microbiology 54, I-I I.

SOKAL, R. R. \& MiChENER, C. D. (1958). A statistical method for evaluating systematic relationships. Kansas University Science Bulletin 38, I409-1438.

Sokal, R. R. \& Sneath, P. H. A. (1963). Principles of Numerical Taxonomy. San Francisco: W. H. Freeman.

Somerville, H. J. \& JoNes, M. L. (1972). DNA competition studies within the Bacillus cereus group of bacilli. Journal of General Microbiology 73, 257-265.

Strandskov, F. B., Baker, H. W. \& Bocklemann, J. B. (1953). A study of the gram-negative bacterial rod infection of brewery yeast and brewery fermentations. Wallerstein Laboratories Communications $\mathbf{1 6}$, $26 \mathrm{I}-270$. 